\title{
PEMBANGUNAN SISTEM PENDUKUNG KEPUTUSAN PENILAIAN KELAYAKAN KREDIT DI KBPR AMANAH, KEPANJEN
}

\author{
A. Shabrina Afrah ${ }^{1}$,Cahya Rahmad ${ }^{2}$, Ariadi Retno Tri. H. $\mathrm{R}^{3}$ \\ ${ }^{1}$ Program Studi Teknik Informatika, ${ }^{2,3}$ Jurusan Teknik Elektro, Politeknik Negeri Malang \\ 1shabrina.taufik@gmail.com
}

\begin{abstract}
Abstrak
KBPR Amanah adalah sebuah BPR (Bank Perkreditan Rakyat) yang terletak di Kecamatan Kepanjen, Kabupaten Malang yang menyediakan layanan kredit, tabungan, dan deposito. Selama ini penilaian kelayakan pengajuan kredit masih dilakukan dengan cara manual.KBPR Amanah Kepanjen merekrut Account Officer sebagai surveyor lapangan untuk melihat kondisi riil dari calon debitur. Kemudian data hasil survei diberikan kepada bagian kredit untuk diperiksa.Kepala Bagian Kredit memiliki kewenangan untuk memutuskan diterima atau tidaknya pengajuan kredit.Banyaknya calon debitur yang mengajukan permohonan kredit dengan kondisi yang berbeda-beda menyebabkan pengambilan keputusan penilaian kelayakan pengajuan kredit menjadi lebih sulit dan membutuhkan kejelian yang tinggi dari pengambil keputusan.Kekurangan pada metode penilaian kelayakan kredit konvensional ini adalah adanya human error yang membuat pengambilan keputusan menjadi kurang akurat.Hal inidapat meningkatkan resiko kredit macet akibat pengambilan keputusan yang kurang tepat mengenai penilaian kelayakan kredit.Maka, dibuat sebuah Aplikasi Sistem Pendukung Keputusan untuk menyelesaikan permasalahan tersebut. Aplikasi ini menggunakan metode TOPSIS (Technique for Order Performance by Similarity to Ideal Solution) karena konsepnya mudah dimengerti, komputasinya efisien, dan memiliki kemampuan untuk mengukur kinerja relatif dari alternatif-alternatif keputusan dalam bentuk matematis yang sederhana. Sistem ini tidak menggantikan peran Bagian Kredit sebagai pengambil keputusan, melainkan dapat menjadi pendamping pengambilan keputusan mengenai kelayakan pengajuan kredit di KBPR Amanah.Dengan adanya aplikasi ini, pengambilan keputusan menjadi lebih efektif, serta menghasilkan keputusan yang terbaik bagi pihak debitur maupun pihak KBPR Amanah.Aplikasi Sistem Pendukung Keputusan ini telah diuji dengan membandingkan hasil keputusan manual dengan kaputusan yang dihasilkan sistem. Berdasarkan hasil pengujian tersebut, tingkat keakuratan SPK dalam penelitian ini mencapai 97,78\%.
\end{abstract}

Kata kunci: Sistem Pendukung Keputusan, Kredit, TOPSIS

\section{PENDAHULUAN}

KBPR Amanah adalah sebuah BPR (Bank Perkreditan Rakyat) yang terletak di Kecamatan Kepanjen, Kabupaten Malang yang menyediakan layanan kredit, tabungan, dan deposito.kredit adalah penyediaan uang atau tagihan yang dapat dipersamakan dengan itu, berdasarkan persetujuan atau kesepakatan pinjam-meminjam antara BPR dengan pihak lain yang mewajibkan pihak peminjam untuk melunasi utangnya setelah jangka waktu tertentu dengan pemberian bunga (Bank Indonesia, 2013).Selama ini penilaian kelayakan pengajuan kredit masih dilakukan dengan cara manual, yaitu dijalankan sepenuhnya oleh Bag. Kredit di KBPR Amanah tanpa bantuan perangkat lunak khusus.

$$
\text { Banyaknya calon debitur yang }
$$
mengajukan permohonan kredit dengan kondisi yang berbeda-beda menyebabkan pengambilan keputusan penilaian kelayakan pengajuan kredit menjadi lebih sulit dan membutuhkan kejelian yang tinggi dari pengambil keputusan.Faktor emosi pengambil keputusan bisa menyebabkan terjadinya human error yang membuat pengambilan keputusan menjadi kurang akurat.Hal ini bahkan dapat berakibat fatal dengan meningkatkan resiko kredit macet akibat pengambilan keputusan yang kurang tepat mengenai penilaian kelayakan kredit.

Salah satu yang dapat dilakukan untuk memperbaiki kekurangan metode konvensional dalam penilaian kelayakan kredit di KBPR Amanah adalah dengan menggunakan sebuah Sistem pendukung Keputusan (SPK).Sistem Pendukung Keputusan adalah suatu sistem yang ditujukan untuk mendukung manajemen pengambilan keputusan (Subakti, 2002).Karakteristik lainnya, SPK dibuat berbasis komputer.Sistem Pendukung Keputusan dapat dibuat dengan berbagai metode.Salah satu metode SPK adalah TOPSIS (Technique for Order Performance by Similarity to Ideal Solution).Metode ini termasuk dalam MCDM (Multi Criteria Decision Making) yaitu suatu metode pengambilan keputusan untuk menetapkan alternatif terbaik dari sejumlah alternatif berdasarkan beberapa kriteria tertentu (Kusumadewi, 2006).

Berdasarkan uraian di atas, perlu dibangun sebuah Sistem Pendukung Keputusan (SPK) untuk mempermudah proses penilaian kelayakan pengajuan kredit oleh nasabah KBPR Amanah dengan metode TOPSIS. Sistem ini tidak menggantikan peran Bag.Kredit sebagai pengambil keputusan, melainkan dapat menjadi pendamping 
pengambilan keputusan mengenai kelayakan pengajuan kredit di KBPR Amanah.

\section{METODETOPSIS}

\subsection{Konsep Dasar}

Technique for Order Performance by Similarity to Ideal Solution (TOPSIS) adalah salah satu metode pengambilan keputusan multikriteria.Metode TOPSIS pertama kali diperkenalkan oleh Yoon dan Hwang (1981). TOPSIS menggunakan prinsip bahwa alternatif yang terpilih harus mempunyai jarak terdekat dari solusi ideal positif dan jarak terpanjang (terjauh) dari solusi ideal negatif untuk menentukan kedekatan relatif dari suatu alternatif dengan solusi optimal.

Solusi ideal positif adalah jumlah dari seluruh nilai terbaik yang dapat dicapai untuk setiap atribut, sedangkan solusi negatif-ideal terdiri dari seluruh nilai terburuk yang dicapai untuk setiap atribut.

\subsection{Kelebihan Metode TOPSIS}

Metode TOPSIS memiliki beberapa kelebihan, yaitu:

-konsepnya sederhana dan mudah dipahami;

-komputasinya efisien; dan

-memiliki kemampuan untuk mengukur kinerja relatif dari alternatif-alternatif keputusan dalam bentuk matematis yang sederhana.

\subsection{Prosedur TOPSIS}

TOPSIS:

Langkah-langkah penilaian metode

Rangking Tiap Alternatif

Pada penelitian ini calon debitur diposisikan sebagai suatu alternatif dan disimbolkan dengan A. Sedangkan kriteria penilaian disimbolkan dengan C. TOPSIS membutuhkan ranking kinerja setiap alternatif $\mathrm{Ai}$ pada setiap kriteria $\mathrm{Cj}$ yang ternormalisasi yaitu :

\section{Rangking Tiap Alternatif}

Pada penelitian ini calon debitur diposisikan sebagai suatu alternatif dan disimbolkan dengan A. Sedangkan kriteria penilaian disimbolkan dengan C. TOPSIS membutuhkan ranking kinerja setiap alternatif $\mathrm{Ai}$ pada setiap kriteria $\mathrm{Cj}$ yang ternormalisasi yaitu :

$$
r_{i j=} \frac{x_{i j}}{\sqrt{\sum_{i=1}^{m} x_{i j}^{2}}}
$$

dengan $i=1,2, \ldots . m ;$ dan $j=1,2, \ldots \ldots . n ;(2.1)$
2. Matriks keputusan ternormalisasi terbobot

$$
\begin{gathered}
y_{i j}=w_{i} r_{i j} \\
\text { dengan } \mathrm{i}=1,2, \ldots, \mathrm{m} \text { dan } \mathrm{j}=1,2, \ldots, \mathrm{n}
\end{gathered}
$$

3. Solusi Ideal Positif Dan Negatif

Solusi ideal positif $\mathrm{A}+$ dan solusi ideal negatif A- dapat ditentukan berdasarkan ranking bobot ternormalisasi (yij) sebagai berikut :

$$
\left.\begin{array}{l}
A^{+}=\left(\begin{array}{l}
y_{1}{ }^{+}, y_{2}{ }^{+}, \ldots, y_{n}{ }^{+} \\
A^{-}=(
\end{array}\right) \\
y_{1}{ }^{-}, y_{2}{ }^{-}, \ldots, y_{n}{ }^{-}
\end{array}\right)
$$

dimana:

$y_{j}{ }^{+}$adalah $\quad:-\max y_{i j}$, jika j adalah atribut keuntungan

- $\min y_{i j}$, jika $\mathrm{j}$ adalah atribut biaya

$y_{j}{ }^{-}$adalah $\quad:-\min y_{i j}$, jika $\mathrm{j}$ adalah atribut keuntungan

- $\max y_{i j}$, jika j adalah atribut biaya

4. Jarak Dengan Solusi Ideal

Jarak adalah alternatif $A_{i}$ dengan solusi ideal positif dirumuskan sebagai:

$$
\begin{aligned}
& D_{i}^{+}=\sqrt{\sum_{j=1}^{n}\left(y_{i}^{+}-y_{i j}\right)^{2}} ; \\
& \mathrm{i}=1,2, \ldots, \mathrm{m}
\end{aligned}
$$

Jarak adalah alternatif $A_{i}$ dengan solusi ideal positif dirumuskan sebagai:

$$
\begin{aligned}
& D_{i}^{-}=\sqrt{\sum_{j=1}^{n}\left(y_{i j}-y_{i}^{-}\right)^{2}} ; \\
& \mathrm{i}=1,2, \ldots, \mathrm{m}
\end{aligned}
$$

5. Nilai Preferensi Untuk Setiap Alternatif

Nilai preferensi untuk setiap alternatif (Vi) diberikan sebagai :

$$
V_{i}=\frac{D_{i}^{-}}{D_{i}^{-}+D_{i}^{+}} \quad ; \mathrm{i}=1,2, \ldots, \mathrm{m}
$$

Nilai Vi yang lebih besar menunjukkan bahwa alternatif Ai lebih dipilih.

\section{HASIL}

3.1 Desain Sistem 


\subsubsection{Use Case Diagram}

Use case diagram merupakan pemodelan untuk kelakuan (behavior) sistem yang akan dibuat (Rosa A.S., 2013).

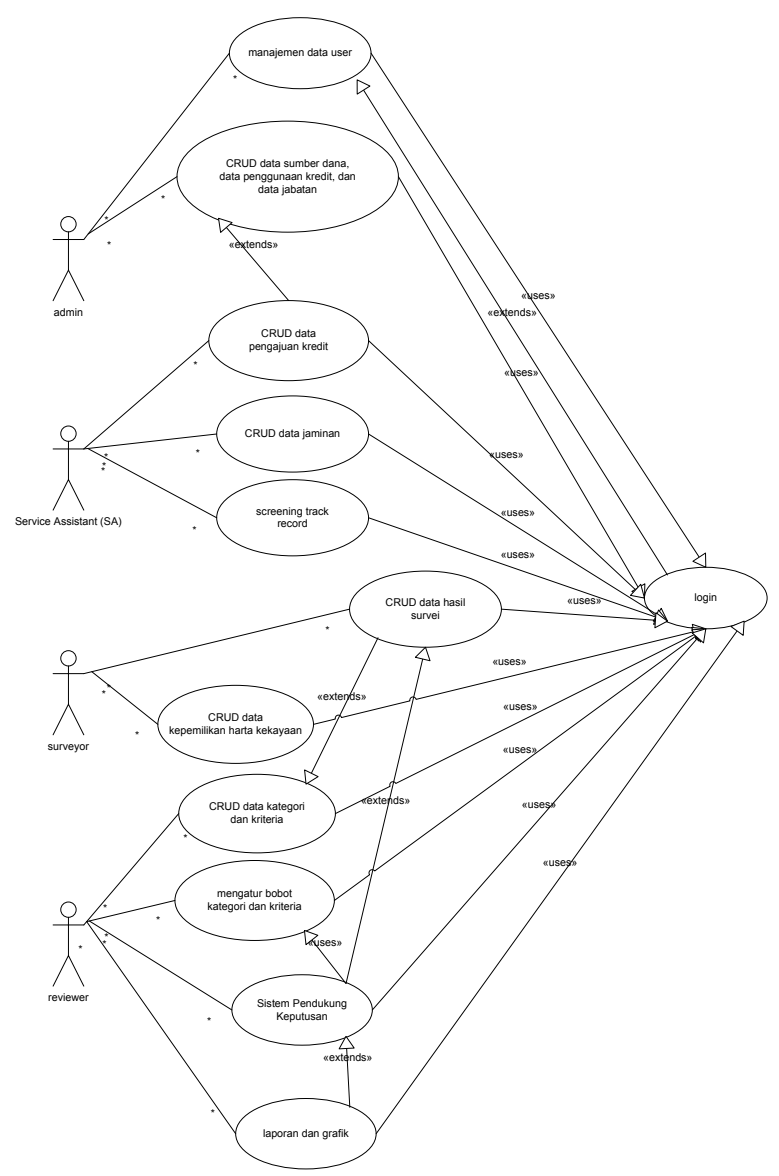

Gambar 3.1: Use Case Diagram

\subsubsection{Context Diagram}

DFD Level 0 atau context diagram biasa disebut sebagai diagram sistem inti (fundamental system model) atau biasa model konteks (context model). Arah panah dari aliran data menunjukkan aliran data berupa masukan (input) dan keluaran (output) ke dalam proses perangkat lunak yang dirancang (Rosa A.S., 2013).

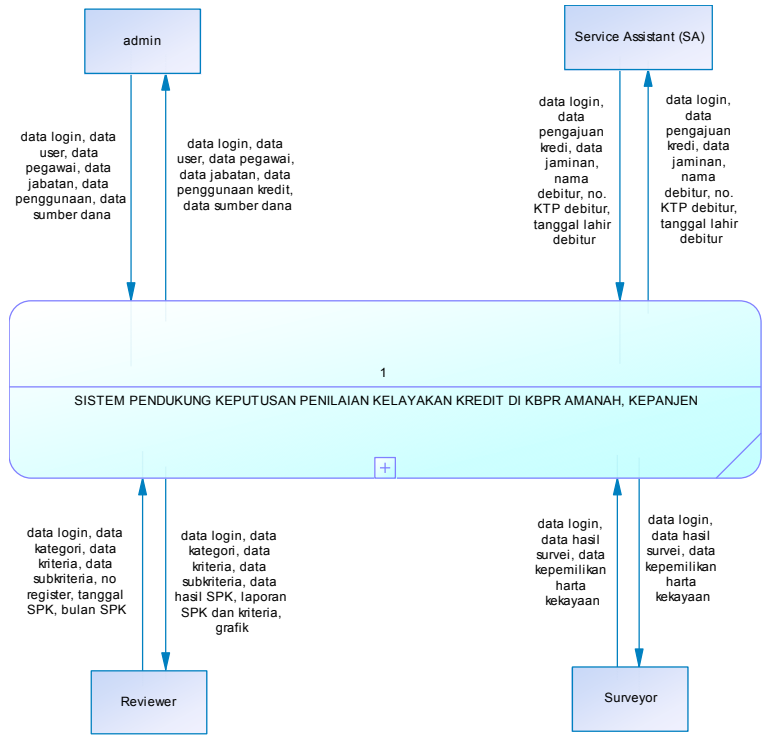

Gambar 3.2: Context Diagram

Aplikasi yang akan dibangun adalah Sistem pendukung Keputusan Penilaian Kelayakan Kredit di KBPR Amanah Kepanjen. User pada sistem ini ada 4, yaitu:

a. Reviewer

Reviewer adalah user yang bertugas untuk mengambil keputusan kelayakan kredit di BPR atau biasa disebut analis kredit. Pada sistem ini reviewer akan diberi otoritas untuk menentukan kriteria dan subkriteria penilaian, menentukan bobot kriteria dan subkriteria, dan menjalankan Sistem Pendukung Keputusan dalam pengambilan keputusan mengenai kelayakan pengajuan kredit.

\section{b. Surveyor}

Surveyor adalah user yang bertugas melakukan survei ke lapangan dan melaporkan hasilnya pada pihak bank. Pada sistem ini surveyor akan diberi otoritas untuk memasukkan data hasil survei ke dalam sistem.

c. $\quad$ Service Assistant (SA)

Service Assistant (SA) adalah user yang bertugas menginputkan data pengajuan kredit berdasarkan formulir pengajuan yang telah diisi oleh calon debitur. Selain itu data pengajuan kredit bisa diedit dan didelete.

\section{d. Admin}

Admin atau administrator akan diberi otoritas untuk memasukkan data peruntukan kredit, data sumber dana, data pegawai/user pada sistem ini, dan data jabatan pegawai/user.

\subsection{Desain Sistem Pendukung Keputusan}

Sistem ini diharapkan mampu menilai kelayakan suatu pengajuan kredit yang terdiri atas 4 penggolongan, antara lain: 
1. Kredit untuk modal usaha yang sumber dana pelunasan kreditnya berasal dari usaha calon debitur.

2. Kredit untuk modal usaha yang sumber dana pelunasan kreditnya berasal dari gaji/honor calon debitur.

3. Kredit untuk konsumsi yang sumber dana pelunasan kreditnya berasal dari usaha calon debitur.

4. Kredit untuk konsumsi yang sumber dana pelunasan kreditnya berasal dari gaji/honor calon debitur.

Karenanya, pada pembangunan Sistem Pendukung Keputusan (SPK) ini digunakan 4 paket kategori, kriteria, dan subkriteria, dimana masing-masing paket memiliki pembobotan kategori dan kriteria yang berbeda-beda. Di bawah ini adalah salah satu contoh pembobotan kategori dan kriteria pada sistem ini:

\begin{tabular}{|c|c|c|c|c|}
\hline No. & Kategori & $\begin{array}{l}\text { Bobot } \\
\text { Katego } \\
\text { ri }\end{array}$ & Kriteria & $\begin{array}{l}\text { Bobot } \\
\text { Kriteria }\end{array}$ \\
\hline 1. & $\begin{array}{l}\text { Capacit } \\
\text { y (C1) }\end{array}$ & 30 & $\begin{array}{l}\text { Pendapatan } \\
\text { rutin bulanan } \\
(\mathrm{C} 1.1)\end{array}$ & 30 \\
\hline 2. & $\begin{array}{l}\text { Collater } \\
\text { al (C2) }\end{array}$ & 30 & $\begin{array}{l}\text { Status } \\
\text { kepemilikan } \\
\text { jaminan } \\
\text { (C2.1) } \\
\text { Nilai jaminan } \\
\text { (C2.2) }\end{array}$ & $\begin{array}{l}12 \\
18\end{array}$ \\
\hline 3. & $\begin{array}{l}\text { Charact } \\
\text { er (C4) }\end{array}$ & 25 & $\begin{array}{l}\text { Kepribadian } \\
\text { calon debitur } \\
\text { (C4.1) }\end{array}$ & 25 \\
\hline 4. & $\begin{array}{l}\text { Conditi } \\
\text { on of } \\
\text { Econom } \\
\text { y (C5) }\end{array}$ & 15 & $\begin{array}{l}\text { Kondisi } \\
\text { ekonomi calon } \\
\text { debitur (C5.1) }\end{array}$ & 15 \\
\hline
\end{tabular}

Tabel 3.1: Pembobotan kategori dan kriteria penilaian pengajuan kredit untuk konsumsi dengan sumber dana dari gaji/honor pegawai

Perhitungan Sistem pendukung Keputusan ini dilakukan berdasarkan data hasil survei calon debitur, nilai batas atas, dan nilai batas bawah yang kemudian diolah dengan perhitungan metode TOPSIS. Nilai batas atas adalah nilai maksimal yang dapat diperoleh seorang calon debitur pada penilaian kelayakan kredit. Nilai batas bawah adalah nilai minimal yang dapat diperoleh seorang calon debitur. Skor maksimal yang dapat diperoleh calon debitur adalah 1 dan suatu pengajuan dinyatakan layak apabila telah mencapai skor 0,8 atau $80 \%$ dari skor maksimal.

\subsection{Implementasi}

\subsubsection{Implementasi Basis Data}

Implementasi basis data dilakukan sesuai dengan perancangan yang telah dilakukan pada bab 4. Basis data yang dibuat diberi nama spk_bpr_amanah.

Pada basis data spk_bpr_amanah terdapat 12 tabel, antara lain tb_pegawai, tb_login, tb_jabatan, tb_peruntukan, tb_sumber_dana, tb_pengajuan, tb_hasil_survei, tb_det_survei, tb_kategori, tb_kriteria, tb_subkriteria, dan tb_penilaian.

\subsubsection{Implementasi Program}

Implementasi Sistem Pendukung Keputusan Penilaian Kelayakan Kredit di KBPR Amanah Kepanjen dilakukan dengan bahasa pemrograman PHP (menggunakan framework CodeIgniter). Sedangkan untuk tampilannya menggunakan bootstrap admin template Simpliq.

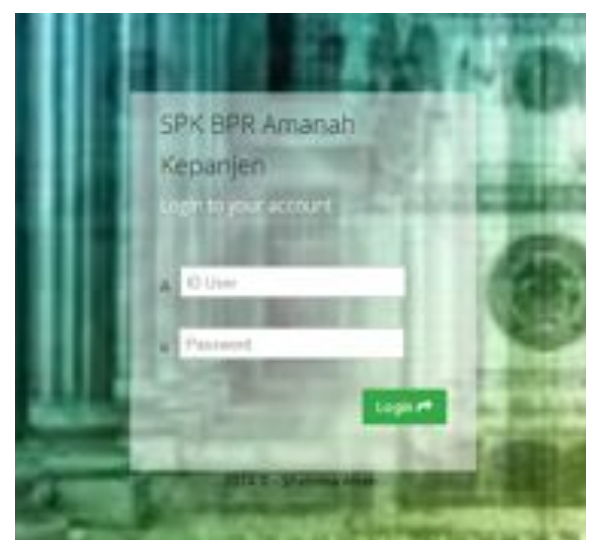

Gambar 3.3: Halaman Login

Gambar 4.2 adalah form login. Untuk dapat masuk ke dalam aplikasi dan menggunakannya user harus mengisi halaman login terlebih dahulu.

User dalam aplikasi ini ada 4, yaitu admin, Service Assistant (SA), surveyor (AO), dan reviewer (Kabag. Kredit dan staff Bag. Kredit). Masing-masing user akan diarahkan ke halaman yang fungsinya berbeda-beda sesuai dengan tugas masing-masing user sebagaimana dijelaskan pada bagian Context Diagram. 


\subsection{Pengujian}

\subsubsection{Pengujian Sistem}

Untuk menguji kinerja aplikasi dibutuhkan suatu pengujian sistem, yaitu pengujian fungsionalitas aplikasi. Pengujian ini dilakukan dengan cara menjalankan setiap fitur dalam aplikasi dan melihat apakah hasilnya sudah sesuai dengan yang seharusnya. Menurut pengujian sistem yang telah dilakukan, fungsi-fungsi dalam sistem ini telah berjalan sesuai perencanaan.

\subsubsection{Pengujian Manual}

Untuk mengetahui validitas hasil keputusan SPK, maka perlu dilakukan pengujian manual. Pengujian manual dilakukan dengan cara mencocokkan skor calon debitur hasil penilaian SPK dengan hasil perhitungan manual. Hasil pengujian manual menunjukkan bahwa output sistem (skor TOPSIS) sudah sama dengan hasil perhitungan manual dengan metode TOPSIS.

\subsubsection{Pengujian Hasil}

Untuk menguji kualitas keputusan yang dihasilkan oleh sistem diperlukan pengujian hasil. Pengujian hasil dilakukan dengan mencocokkan keputusan hasil eksekusi aplikasi dengan keputusan yang diambil secara manual oleh pihak Bagian Kredit KBPR Amanah Kepanjen. Di bawah ini adalah hasil keputusan Sistem Pendukung Keputusan dibandingkan dengan pengambilan keputusan secara manual pada data uji riil.

\begin{tabular}{|l|l|l|l|}
\hline $\begin{array}{c}\text { No. } \\
\text { Register }\end{array}$ & \multicolumn{1}{|c|}{ Nama } & $\begin{array}{c}\text { Hasil } \\
\text { Keputusan } \\
\text { BPR }\end{array}$ & \multicolumn{1}{|c|}{$\begin{array}{c}\text { Hasil } \\
\text { SPK }\end{array}$} \\
\hline 6 & Suwandi & Diterima & Diterima \\
\hline 7 & Jamuri & Diterima & Diterima \\
\hline 8 & Darmadi & Diterima & Diterima \\
\hline 9 & Purnomo & Diterima & Diterima \\
\hline 10 & $\begin{array}{l}\text { Sri } \\
\text { Subandriah }\end{array}$ & Diterima & Diterima \\
\hline 11 & Herianto & Diterima & Diterima \\
\hline 12 & Samoekri & Diterima & Diterima \\
\hline 13 & Hadi & Diterima & Diterima \\
\hline 14 & Budiarto & Diterima & Diterima \\
\hline 15 & Misdi & Diterima & Diterima \\
\hline 16 & Bonadi & Diterima & Diterima \\
\hline 17 & $\begin{array}{l}\text { Aris } \\
\text { Setyawan }\end{array}$ & Diterima & Diterima \\
\hline 18 & $\begin{array}{l}\text { Siti } \\
\text { Maslikah }\end{array}$ & Diterima & Diterima \\
\hline
\end{tabular}

Tabel 5.2: Hasil Pengujian Hasil
Sistem Pendukung Keputusan (SPK) dalam penelitian ini bersifat dinamis. Artinya, user dapat mengatur kategori, kriteria, dan subkriteria beserta bobot kategori dan kriteria. Untuk membuktikannya, dibutuhkan uji sensitifitas, yaitu pengujian hasil SPK apabila kategori, kriteria, dan subkriteria ditambah.

Untuk pengujian ini, ditambahkan 1 buah kategori yang diberi nama "Tambahan" untuk penggolongan kredit untuk konsumsi dengan sumber dana pelunasan kredit dari gaji/honor pegawai dengan bobot 1 . Untuk kategori baru ini dimasukkan sebuah kriteria yang diberi nama "Tambahan 1" dengan bobot 1. Untuk validitas bobot, maka, kategori Capacity dan kriterianya diubah bobotnya menjadi 29 (sebelumnya 30). Setelah itu, juga ditambahkan 2 subkriteria untuk kriteria "Tambahan 1".

Setelah itu dimasukkan data calon debitur dengan no. register 53 (Nadia) dijalankan. Data penilaian calon debitur ini sama dengan data penilaian calon debitur dengan nomor register 51 (Fariz), kecuali pada kriteria "Tambahan 1".

Hasil SPK calon debitur Nadia ternyata menunjukkan perbedaan dengan hasil SPK calon debitur Fariz. Skor calon debitur Nadia menunjukkan nilai 0.687197 , sedangkan skor calon debitur Fariz adalah 0.690866 (Tabel 5.2).

\section{PEMBAHASAN}

Berdasarkan pengujian sistem yang telah dilakukan, dapat diketahui bahwa sistem pada penelitian ini telah berjalan dengan baik secara fungsional dan menghasilkan output yang diharapkan. Berdasarkan pengujian manual, dapat diketahui bahwa SPK pada penelitian ini telah berjalan dengan baik dan menghasilkan hasil yang sama dengan perhitungan manual dengan metode TOPSIS. Hal ini didukung dengan pengujian hasil yang menunjukkan bahwa 44 dari total 45 data pengujian baik data riil maupun data simulasi telah menghasilkan keputusan sesuai dengan yang diharapkan. Dengan demikian tingkat keakuratan hasil keputusan SPK pada penelitian ini adalah sebesar 97,78\%.

Di bawah ini adalah grafik yang menggambarkan jumlah pengajuan diterima dan ditolak oleh BPR dan SPK:

\subsubsection{Uji Sensitifitas}




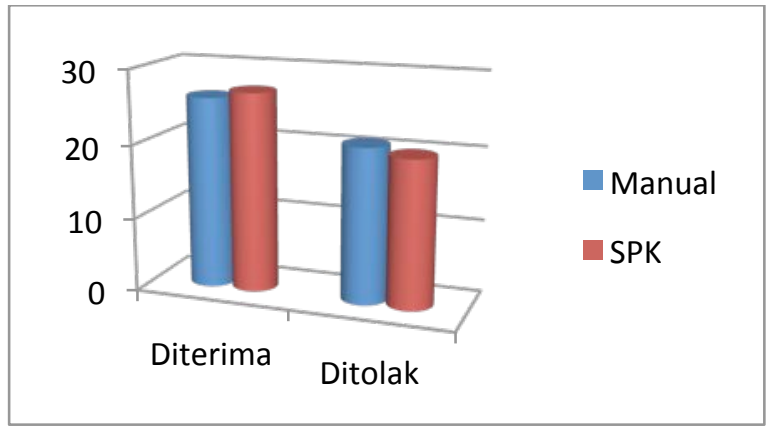

Gambar 4.1: Grafik perbandingan hasil penilaian manual oleh BPR dengan hasil penilaian SPK

Pada pengujian hasil, terdapat 1 data simulasi yang ternyata menghasilkan keputusan yang berbeda antara sistem dengan keputusan manual dari BPR, yaitu pada calon debitur dengan nomor register 42 (Wawan). Perbedaan ini disebabkan pada pembobotan kategori dan kriteria yang masih perlu disempurnakan.

Pengujian terakhir adalah uji sensitivitas. Berdasarkan pembahasan sebelumnya telah diketahui bahwa pengujian ini menghasilkan kesimpulan dengan data penilaian yang sama skor akhir sebelum kriteria tambahan dimasukkan dan sesudahnya berbeda. Hal ini menunjukkan bahwa sistem ini telah berjalan baik dan sesuai seperti yang diharapkan.

\section{KESIMPULAN DAN SARAN}

\section{Kesimpulan}

Berdasarkan pembahasan pada bab 1 hingga 6 dapat ditarik beberapa kesimpulan, yaitu:

a. Sistem ini telah berhasil menerapkan metode TOPSIS untuk pengambilan keputusan penilaian kelayakan kredit di KBPR Amanah.

b. Hasil pengujian menunjukkan bahwa perancangan sistem telah menghasilkan sistem yang dapat membantu pengambilan keputusan penilaian kelayakan kredit secara otomatis. Hasil pengujian juga menunjukkan bahwa sistem ini telah bersifat dinamis.

c. Hasil pengujian menunjukkan bahwa performansi sistem ini sudah baik dan menghasilkan hasil yang akurat. Hasil pengujian hasil menunjukkan bahwa 44 data dari total 45 data uji baik data riil maupun data simulasi $(97,78 \%)$ telah menunjukkan hasil yang seimbang antara keputusan sistem dengan keputusan manual.

\section{Saran}

Berdasarkan penelitian ini, saran penulis adalah perlu dilakukan perbaikan bobot pada SPK dalam penelitian ini. Dengan demikian, diharapkan hasil penilaian bisa lebih baik.

\section{DAFTAR PUSTAKA}

Y.I.E., Baskworo, Soebroto, A.A, dan Regasari, Rekyan. 2013. Sistem Pendukung Keputusan Penentuan Kelayakan Pengisian Bibit Ayam Broiler Dikandang Peternak menggunakan Metode AHP dan TOPSIS. Program Studi Ilmu Komputer, Jurusan Ilmu KomputerFakultas Program Teknologi Informasi dan Ilmu Komputer Universitas Brawijaya. Malang: Universitas Brawijaya

Kusumadewi, S., Hartati, S., Harjoko, A., dan Wardoyo, Retantyo. 2006. Fuzzy Multi-Attribute Decision Making (Fuzzy MADM). Yogyakarta: Graha Ilmu

Oktaputra, A.W., dan Noersasongko, Edi. 2014. Sistem Pendukung Keputusan Kelayakan Pemberian Kredit Motor menggunakan Metode Simple Additive Weighting pada Perusahaan Leasing Hd Finance. Program Studi Sistem Informasi - S1, Fakultas Ilmu Komputer Universitas Dian Nuswantoro. Semarang: Universitas Dian Nuswantoro

Pedoman Penyusunan Laporan Bulanan Bank Perkreditan Rakyat, Bank Indonesia, 2013

S.A., Rosa, dan Shakahudin, M. 2013. Rekayasa Perangkat Lunak Terstruktur dan Berorientasi Objek. Bandung: Informatika

Subakti, Irfan. 2002. Sistem pendukung Keputusan. Surabaya: Institut Teknologi sepuluh Nopember 